\title{
A ONTOLOGIA COMO NOVA IDEOLOGIA ALEMÃ: ADORNO E A CRÍTICA DA CARÊNCIA ONTOLÓGICA
}

\author{
Ontology as a new German ideology: Adorno and the critique of ontological need
}

Luiz Philipe de Caux *

Resumo: $\mathrm{O}$ artigo oferece uma interpretação do conceito adorniano de carência, foco do primeiro capítulo da primeira parte da Dialética Negativa. Pretende provar a centralidade desse conceito para a compreensão, não só da crítica de Adorno à ontologia fundamental heideggeriana, mas também, da sua noção de crítica imanente em geral. Para alcançar esse objetivo, o artigo reconstrói o tratamento do conceito de carência em Kant, Hegel e no jovem Marx, indicando como esse tratamento viria a exercer influência em Adorno. Em seguida, mostra-se como tal conceito é atualizado por ele a partir do diagnóstico de tempo do capitalismo tardio, e quais as consequências dessa reconfiguração para a formulação de uma dialética negativa.

Palavras-chave: Teoria crítica da sociedade. Theodor W. Adorno. Martin Heidegger. Carência. Capitalismo tardio.

Abstract: The article offers an interpretation of the Adornian notion of ontological need, focal point of the first chapter of Negative Dialectics, part 1. It argues that this conception is central to understanding not only Adorno's criticism of Heidegger's fundamental ontology, but also, more generally, his notion of immanent criticism. In order to prove this centrality, the paper reconstructs how the notion of need is dealt with by Kant, Hegel, as well as by the young Marx, and how such comprehension would influence Adorno's thinking. Then, it examines how the notion of need is updated by Adorno himself from the time diagnosis of late capitalism he establishes, and the consequences of this reconfiguration for the formulation of his own negative dialectics.

Keywords: Critical theory of society. Theodor W. Adorno. Martin Heidegger. Need. Late capitalism.

* Doutor em Filosofia pela UFMG. Professor do Departamento de Filosofia da UFRN. Artigo recebido em 25/05/2019 e aprovado para publicação em 15/10/2019. 
A produção não apenas fornece à carência um material, ela também fornece ao material uma carência.

K. Marx

\section{Introdução}

$\mathrm{E}$ m que pese toda a documentação acerca da relação extremamente complexa e mesmo hostil daqueles dois filósofos que Zuidervaart chama de "os extremos dialéticos da filosofia alemã do século XX", pouca atenção foi dada até o presente ao fato de que a Dialética Negativa, obra síntese do pensamento maduro de Theodor W. Adorno, faz seguir a seu capítulo introdutório justamente uma crítica das correntes ontológicas em voga à época desde algumas décadas, cujo cume em originalidade, elaboração e influência é com justiça atribuído a Heidegger. Por que a Dialética Negativa tem início, afinal, com dois capítulos dedicados centralmente à ontologia fundamental? Se a atribuição do adjetivo negativa à dialética leva de imediato o leitor a crer que se trata ali de um diálogo corretivo com Hegel, talvez com Marx, por que a primeira das partes deste livro é dedicada a Heidegger, um autor que assume uma posição de quase total externalidade em relação aos pressupostos da tradição dialética? Ainda menos considerado pela recepção de Adorno é o fato de que o primeiro desses capítulos não se dedica desde o início a uma crítica imediata do conteúdo conceitual da filosofia heideggeriana, mas opera antes por um desvio através de uma forma de crítica que poderia ser inadvertidamente classificada como apenas externa àquele conteúdo. Pois, referindo-se em particular, mas não apenas, à ontologia fundamental heideggeriana, Adorno constata já na primeira página deste capítulo que "sua influência não seria compreensível se não viesse a seu encontro uma carência enfática, índice de algo que foi perdido (eines Versäumten)". ${ }^{2}$ Mesmo o volumoso livro de Hermann Mörchen, que documenta exaustivamente a relação (e a não-relação) entre os dois filósofos, não dedica mais do que quatro páginas ao problema dessa carência. ${ }^{3}$

\footnotetext{
${ }^{1}$ ZUIDERVAART, Lambert. Social Philosophy after Adorno. Cambridge, UK: Cambridge UP, 2007, p. 77. Indico sempre que possível a obra citada no original e, se for o caso, a tradução disponível em português consultada. As traduções citadas poderão vir modificadas. As que não forem acompanhadas da indicação da tradução para o português são igualmente de minha responsabilidade.

${ }^{2}$ AGS 6, p. 69; trad.: ADORNO, Theodor W. Dialética negativa. Trad. M. A. Casanova. Rev. E. S. N. Silva. Rio de Janeiro: Zahar, 2009, p. 59. No curso Ontologia e Dialética, Adorno utiliza também a expressão "Index eines Fehlenden" ("índice de algo que falta") (ADORNO, Theodor W. Ontologie und Dialektik (1960/61). Hrsg. R. Tiedemann. Frankfurt a.M.: Suhrkamp, 2002, p. 152). ${ }^{3}$ MÖRCHEN, Hermann. Adorno und Heidegger: Untersuchung einer philosophischen Kommunikationsverweigerung. Stuttgart: Klett-Cotta, 1981, p. 297-300.
} 
A Dialética Negativa não apenas toma por seu primeiro objeto, de um modo que é de início pouco claro no texto, a figura original assumida pela ontologia em Heidegger, ${ }^{4}$ como ainda a aborda de um ponto de vista que dificilmente se deixa classificar prima facie como algo distinto de uma crítica externa (portanto, não dialética, na concepção do próprio Adorno): o primeiro objeto da reformulação adorniana da dialética é uma determinada carência humana historicamente dada, a carência pelo pensamento de pretensões ontológicas, ou a que Adorno chama sinteticamente de $\mathrm{ca}$ rência ontológica. ${ }^{5}$ Tendo, na primeira das aulas do seu curso do semestre de inverno de 1960/61, de título Ontologia e Dialética, afirmado que "a via do pensamento dialético é (...) a da crítica imanente", e que é por essa via que o pensamento de Heidegger deveria ser abordado, Adorno completa na frase seguinte: "Parto, portanto, da carência que existe hoje da ontologia". ${ }^{6}$ Do mesmo modo, no prefácio da Dialética Negativa, o lugar dessa crítica é assim descrito: "Essa ontologia não é julgada de uma posição mais elevada, mas compreendida a partir de sua carência - uma carência, por sua vez, problemática - e criticada de maneira imanente". ${ }^{7}$ A opacidade da linha de raciocínio deve desconcertar o leitor ainda não familiarizado com o conteúdo da crítica. Pois criticar um pensamento filosófico a partir do caráter das carências subjetivas que conduzem o filósofo a formulá-lo ou os seus leitores a por ele se interessarem parece ser tudo, salvo uma crítica imanente desse pensamento. ${ }^{8}$

\footnotetext{
${ }^{4}$ Naturalmente, a eleição de Heidegger como objeto da crítica só poderia ser, de início, obscura no universo fechado de uma leitura da Dialética Negativa apartada do desenvolvimento intelectual de Adorno. A crítica a Heidegger no livro de 1966 é precedida por uma crítica desenvolvida ocasionalmente na Metacrítica da teoria do conhecimento, de 1956, e outra bastante direta em Jargão da autenticidade, de 1964, para não falar no interesse crítico precocemente manifestado na aula inaugural de Adorno em Frankfurt, "A atualidade da filosofia", de 1931. ${ }^{5}$ A tradução brasileira de Marco Antonio Casanova da Dialética Negativa, revisada por Eduardo Neves Silva, opta por verter "ontologisches Bedürfnis" por "necessidade ontológica". Com efeito, a opção por verter Bedürfnis por "necessidade" é irreprochável. Opto, todavia, pelo vocábulo "carência", por um lado, para evitar a confusão com o sentido modal de necessidade, e, por outro, para manter o conceito mais próximo do sentido ao mesmo tempo corpóreo e econômico do termo, mais afinado com a interpretação que pretendo avançar, sentido que resta claro, por exemplo, quando Hegel denomina o primeiro momento da sociedade civil-burguesa, na Filosofia do Direito, como System der Bedürfnisse, "sistema das carências", como consta na tradução de Marcos Müller (HEGEL, 2003, p. 21). Outras opções de tradução de Bedürfnis encontradas na literatura filosófica em português são "demanda", "precisão" e "carecimento". Opções de tradução de outras línguas europeias foram: "necesidad" (trad. para o espanhol de A. B. Muñoz), "bisogno" (trad. para o italiano de C. A. Donolo), "besoin" (trad. para o francês do Grupo de Tradução do Collège de Philosophie) "need" (trad. para o inglês de E. B. Ashton). ${ }^{6}$ ADORNO, Theodor W. Ontologie und Dialektik (1960/61), op. cit., p. 12.

7 AGS 6, p. 10; ADORNO, Theodor W. Dialética negativa, op. cit., p. 8.

${ }^{8} \mathrm{O}$ foco da crítica na carência ontológica parece ser um dos casos ao qual se aplica a observação de Gandesha: "Apesar da importância do pensamento de Heidegger como um pano de fundo do seu próprio pensamento, o comportamento de Adorno para com Heidegger era de vez em quando abrasivamente polêmico, mesmo ao ponto de pôr em risco sua intenção declarada de fornecer uma leitura imanentemente crítica de seu adversário filosófico" (GANDESHA, Samir. Leaving Home: On Adorno and Heidegger. HUHN, Tom (ed.). The Cambridge Companion to Adorno. Cambridge, UK: Cambridge UP, 2004, p. 103-4).
} 
Na leitura recente avançada por Dieter Thomä, a separação dos dois capítulos da Parte I da Dialética Negativa, "A carência ontológica" e "Ser e existência" (nesta ordem), é tomada como de menor relevância para a interpretação da obra e da crítica adorniana a Heidegger. Segundo o autor, "essa distinção desperta a aparência de que ocorre primeiramente uma consideração externa do interesse manifestado pelo 'ser' e depois uma análise sua [do ser]". Tal aparência, todavia, não se sustentaria, já que o próprio texto de Adorno não permite que se mantenha uma separação estrita entre os dois níveis. ${ }^{9}$ Se parece claro que o procedimento constelatório urdido por Adorno como modo de exposição tem por uma de suas características exatamente não permitir separações estanques, que se apresentassem como passos de um raciocínio analítico, ${ }^{10}$ isso não quer dizer, todavia, que a crítica da carência ontológica componha simplesmente o bloco de argumentos indiviso da crítica do conteúdo conceitual da ontologia fundamental. Thomä tende a reunir os dois capítulos não para efetivamente demonstrar como os argumentos operam em conjunto, fazendo da crítica da carência ontológica um momento da crítica imanente da ontologia fundamental, mas sim para deflacionar o papel da crítica da carência ontológica na argumentação de Adorno, ou mesmo para caracterizá-la como um argumento filosoficamente fraco, evitando assim compreender o seu lugar e, sobretudo, escamoteando toda a amplitude do sentido de crítica imanente utilizado por Adorno. Thomä argumenta que

Com o conceito da 'carência', que assume no título do capítulo 'A carência ontológica' uma posição proeminente, Adorno não alude a algo como uma pulsão natural, mas quer poder explicar a busca do ser como um mero sintoma. Então ele vê nesse conceito a oportunidade de historicizar a virada em direção à ontologia e interpretar o ser como superfície de projeção de um desejo liberado. Mas essa abordagem padece de diversos problemas. De um lado, não é possível simplesmente livrar o conceito de carência de seu conteúdo filosófico-psicológico (...). Por outro lado, é de se perguntar em que medida uma tendência historicamente emergente pode ser repudiada de algum modo pela sua designação como 'carência'; por fim, Adorno mesmo conhece tendências plenamente históricas que não lhe aparecem de modo algum como depreciáveis, mas sim como altamente respeitáveis histórico-filosoficamente. (...). O que se ganha ao reduzir o último a uma 'carência'? A navalha de crítica da ideologia que Adorno associa ao conceito de carência fica sem o fio. ${ }^{11}$

\footnotetext{
9 THOMÄ, Dieter. Verhältnis zur Ontologie: Adornos Denken des Unbegrifflichen. In: HONNETH, Axel; MENKE, Christoph (eds.).Theodor W. Adorno: Negative Dialektik. Berlim: Akademie Verlag, 2006, p. 30.

${ }^{10}$ Sobre o procedimento constelatório, cf. NEVES SILVA, Eduardo S. Filosofia e arte em Theodor W. Adorno: A categoria da constelação. Tese (Doutorado). Programa de Pós-Graduação em Filosofia, Faculdade de Filosofia e Ciências Humanas, Universidade Federal de Minas Gerais. Belo Horizonte, 2006.

${ }^{11}$ THOM $\ddot{A}$, Dieter. Verhältnis zur Ontologie, op. cit., p. 40-41.
} 
Gostaria, no que segue, de me opor à posição de Thomä e demonstrar que uma consideração adequada do papel da crítica da carência ontológica é decisiva ao menos por três motivos: a) de imediato, para a compreensão da crítica de Adorno a Heidegger; b) de modo mais amplo, para a compreensão do projeto da Dialética Negativa como um todo, assumindo como relevante o fato de que o livro tem início, após sua introdução, com a crítica da carência ontológica e que o conteúdo que constitui o início do movimento dialético não pode ser arbitrário, ao menos nas formas assumidas pela dialética em Hegel e Marx (e não há motivos para se crer que a centralidade decisiva do conteúdo do início da exposição dialética seja revista pela dialética negativa, mesmo que adquira ali um outro significado), e c) de modo indireto, para a compreensão da modulação da noção de crítica imanente no Adorno tardio, uma vez que o uso do conceito para caracterização da crítica da carência ontológica parece desafiar a sua compreensão habitual. Parto, para tanto, de uma breve investigação da ascendência do conceito de carência ontológica de Adorno no período da filosofia clássica alemã. $O$ tema da carência de uma certa figura de pensamento de pretensões elevadas compareceu, de formas distintas, em Kant, no jovem Hegel e no jovem Marx. Em que pese tais fontes não serem textualmente indicadas por Adorno, argumento que elas compõem o caldo do qual se nutre a crítica da carência ontológica. Num segundo momento, passo propriamente à crítica adorniana, buscando insumos interpretativos na tematização do conceito de carência em outros de seus textos. À guisa de conclusão, tentarei tematizar muito sumária e provisoriamente o sentido da crítica imanente em Adorno e o lugar da consideração de Heidegger para uma renovação da dialética.

\section{A carência filosófica na filosofía clássica alemã}

\section{I.1. Kant e a carência metafísica da razão}

É em Kant que podemos encontrar a referência mais remota da noção adorniana de uma carência ontológica. ${ }^{12}$ Conhece-se já do prefácio de 1781 à Crítica da Razão Pura aquele "peculiar destino" da razão, o destino

\footnotetext{
${ }^{12}$ A noção de uma espécie de carência dirigida a algo de elevadamente espiritual ou ideal se encontra, por certo, em Platão, exemplarmente no discurso de Diotima a Sócrates, narrado pelo último em sua participação no Banquete (201d-212b). O próprio Kant remete genericamente a Platão a ideia de que "nossa faculdade de conhecimento sente uma carência muito mais elevada do que a de descrever meros fenômenos segundo a unidade sintética para poder lê-los como experiência, e que a nossa razão ascende naturalmente a conhecimentos que vão
} 
de ter, por sua própria natureza, de se colocar questões que, todavia, não é capaz de responder. ${ }^{13} \mathrm{O}$ projeto de uma crítica da razão, isto é, o de traçar os limites legítimos dentro dos quais ela pode se mover, só é necessário porque a razão possui uma tendência espontânea a operar sem a consideração de quaisquer limites, impelida a buscar de modo infinito um incondicionado que condicione a série de condições que ela descobre inferencialmente; incondicionado, todavia, que ela nunca encontra de fato, mas apenas a cada vez de modo precário e ilusório.

Diferentemente da faculdade do entendimento, pacificada a cada vez que é capaz de apreender pelo conceito um objeto empírico, a faculdade da razão nunca encontra sossego, na medida em que pode operar como que no vazio, sem a resistência do material recebido pela intuição. E não apenas pode fazê-lo, como não pode não fazê-lo, pois, ao se deparar com um conteúdo que ela ainda não foi capaz de sintetizar e ao se inteirar dessa sua falta, ela é impelida a encontrar uma nova síntese, síntese novamente fadada a mostrar-se parcial, engendrando o mesmo processo ad infinitum. Por isso, Kant não hesita em dizer que a razão possui nela mesma uma carência, um algo que lhe falta, de que ela precisa e que se esforça por obter. E é essa carência que faz dela a razão. Todos os construtos da metafísica dogmática, para Kant, são oriundos dessa carência, de modo que a especulação que extrapola o conteúdo dos sentidos é uma "disposição natural" do ser humano dotado da faculdade da razão. É essa disposição, ao mesmo tempo natural e engendradora de ilusões necessárias, que dá toda a seriedade ao projeto de uma crítica da razão. Na introdução à segunda edição da primeira Crítica, Kant assim a caracteriza:

No entanto, também esse tipo de conhecimento [i.e., o da metafísica], em certo sentido, tem de ser visto como dado, e a metafísica é real, se não como ciência, ao menos como disposição natural (metaphysica naturalis). Pois a razão humana, sem ser movida pela mera vaidade da erudição, mas impulsionada pela própria carência, avança incessantemente até tais questões que não podem ser respondidas por nenhum uso empírico da razão, nem com princípios daí emprestados; e em todos os seres humanos, assim, tão logo a razão se tenha estendido neles até a especulação, houve em todos os tempos alguma metafísica, e sempre continuará a haver. Também para ela, pois, vale a questão: como é possível a metafísica como disposição natural? Ou seja: como surgem, a partir da natureza da razão humana universal, as questões que a razão se coloca e procura responder, da melhor maneira possível, impulsionada por sua própria carência? ${ }^{14}$

muito além daquilo com que algum objeto dado pela experiência possa ser congruente, mas que nem por isso deixam de ter a sua realidade e não são meras fantasias" (KrV B, AA 03, p. 246; trad. p. 287). O que importa a Adorno, todavia, é a reelaboração do problema na modernidade capitalista, motivo pelo qual a essa sintética reconstrução remonta apenas até Kant.

${ }^{13} \mathrm{KrV}$ A, AA 04, p. 7; trad. p. 17.

${ }^{14} \mathrm{KrV}$ B, AA 03, p. 41; trad. p. 58. 
O caráter inerentemente carente da razão faz brotar todo um sistema de enunciados metafísicos que a própria razão, posteriormente e mediante a crítica que faz de si mesma, vem a descobrir como sem qualquer direito de aspirar à verdade. Mas, se a metafísica como ciência não é real, ela o é como disposição natural do homem dotado de razão. Se a própria carência possui um caráter transcendental, i.e., é postulada como condição de possibilidade da atividade racional, essa atividade é posta em marcha pelos homens (empíricos) dotados de razão. A própria razão, diz Kant, "não sente; ela discerne a sua falta (Mangel) e, mediante o impulso para o conhecimento (Erkenntnistrieb), põe em operação (wirkt) o sentimento da carência" ${ }^{15}$ A razão ela mesma não sente a carência, mas opera objetivamente provocando (wirken) um "sentimento da carência".

A crítica não descobre apenas os momentos em que a carência da razão a impele a ultrapassar seus limites legítimos, mas ainda, num mesmo golpe, os momentos em que ela opera não apenas de facto, como também de jure. Pois, a partir da crítica, é possível distinguir entre uma carência da razão pura e uma carência da razão prática pura. “Uma carência da razão pura em seu uso especulativo conduz somente a hipóteses, mas a carência da razão prática pura conduz a postulados" ${ }^{16}$ Enquanto a carência da razão pura, impelindo a razão a realizar enunciados teóricos sem conteúdo empírico, pode legitimamente apenas conduzir a hipóteses que precisam de confirmação empírica posterior, ${ }^{17}$ a carência da razão pura prática leva legitimamente à formação de postulados que a razão, enquanto faculdade prática de pôr fins no mundo, se vê vinculada por dever a realizar.

Entra em cena aqui, porém, o direito da carência da razão, como fundamento subjetivo para pressupor e admitir algo que ela, com fundamentos objetivos, não pode permitir-se saber; e, por conseguinte, [como fundamento] para se orientar tão somente por sua própria carência no pensamento, no incomensurável e no espaço do suprassensível, preenchido pela noite densa. ${ }^{18}$

Enquanto faculdade prática, a razão possui uma carência em todos os casos legítima, que possui o direito de aspirar por um incondicionado e o dever de realizá-lo no mundo (agindo "como se" eles fossem o caso). Tais postulados a que conduz a carência da razão prática são aqueles velhos objetos da metaphysica specialis, a imortalidade da alma, a liberdade e a existência de Deus. Assim, "uma carência da razão prática pura está

\footnotetext{
${ }^{15}$ WDO, AA 08, p. 139n; trad. p. 29.

${ }^{16} \mathrm{KpV}$, AA 05, p. 142; trad. p. 182.

17 “(...) pois no primeiro caso, a partir do derivado, eu remonto, na série dos fundamentos, tão alto quanto eu queira e careço de um fundamento originário não para dar realidade objetiva àquele derivado (por exemplo, à ligação causal das coisas e suas mudanças no mundo), mas apenas para satisfazer completamente a minha razão investigadora em vista desse derivado" (KpV, AA 05, p. 142; trad. p. 182).

${ }^{18}$ WDO, AA 08, p. 137; trad. p. 26.
} 
fundada em um dever de adotar algo (o sumo bem) como objeto de minha vontade, para promovê-lo com todas as minhas forças". ${ }^{19}$

Como nota Joel Klein, é esclarecedor contrapor ao conceito kantiano de carência (por ele vertido como "precisão") o seu oposto, a ausência de carência (Bedürfnislosigkeit). Apenas um ente infinito, divino, não sente carências, pois é completo e nada lhe falta. A ausência de carências é um estado pacificado, aquele mesmo tomado como ideal tanto pelos cínicos quanto pelos estoicos. A carência da razão dá mostras, portanto, justamente de seu caráter humano, finito. A razão, tratada como é ao nível transcendental, é sempre posta em operação por sujeitos empíricos.

Portanto, falar de uma Bedürfnis [carência] aplicada à faculdade cognoscitiva significa levar em conta três propriedades fundamentais da razão pura: a finitude; a discursividade; e, o caráter ativo das faculdades superiores de conhecimento. Numa razão que fosse infinita e intuitiva, tal como se pensa no modelo de um intellectus archetypus atribuído a Deus, não faz sentido falar de Bedürfnisse, pois o simples ato de pensar o objeto já implicaria em sua existência, juntamente com todas as suas propriedades. Tratar-se-ia de uma razão autossuficiente e supostamente inativa (pelo menos no sentido de como se pensa a atividade da razão humana). Assim, atribuir diversas Bedürfnisse à razão humana significa aceitar que ainda que ela seja finita e discursiva, ela também pode, por meio da sua atividade, criar um todo sistemático com sentido. ${ }^{20}$

Kant caracteriza a razão, portanto, como carente, insatisfeita, dotada sempre de uma falta à qual ela busca superar por meios legítimos e ilegítimos. Ela é carente enquanto é razão humana, realizada no mundo fenomênico. Nesse sentido, se a própria razão não sente, mas opera objetivamente realizando um sentimento de carência, parece razoável supor que os sujeitos empíricos sintam efetivamente essa carência de a cada vez buscar, por novas e novas sínteses, um incondicionado. São, de resto, sujeitos empíricos que têm a "disposição natural" à metafísica e que, sentindo a carência, formularam os grandes sistemas metafísicos, quer sejam filosóficos ou religiosos. Essa carência não se manifesta empiricamente apenas nas formulações teóricas desses sistemas, mas nos postulados morais que têm por horizonte a realização no mundo do reino dos fins. Ela impele, portanto, não apenas à formulação falsa de ideais sem conteúdo empírico, mas igualmente à postulação correta de ideais a serem realizados, visando superar a carência não por objetos teóricos, mas efetivamente, pela prática - ainda que essa realização prática deva aqui permanecer como um puro e impotente dever-ser.

\footnotetext{
${ }^{19} \mathrm{KpV}$, AA 05, p. 142; trad. p. 182.

${ }^{20} \mathrm{KLEIN}$, Joel. Sobre o significado e a legitimidade transcendental dos conceitos de precisão, interesse, esperança e crença na filosofia kantiana. Veritas, 59, 1, 2014, p. 155.
} 


\section{I.2. O jovem Hegel e a carência da filosofia}

"O tópico da necessidade da filosofia" no jovem Hegel, explica Joãosinho Beckenkamp, "havia se estabelecido na esteira da discussão da noção kantiana de necessidade (Bedürfnis) da razão". ${ }^{21}$ Ainda segundo Joãosinho, "o uso desta noção no contexto da Querela do Panteísmo", isto é, na intervenção que Kant realiza nessa querela com o texto "O que quer dizer: orientar-se no pensamento?", "terá contribuído para torná-la central no desenvolvimento do idealismo alemão em meados dos anos 1790 (p. ex., em Hölderlin)". ${ }^{22}$ No entanto, como nota Ricardo Crissiuma, "o carecimento que Hegel identifica à sua época, no entanto, já não seria o mesmo carecimento ao qual a filosofia kantiana buscou conferir satisfação", pois "o novo carecimento da filosofia a que a filosofia hegeliana busca apreender e conferir satisfação exige uma reformulação de como pensar a própria relação da filosofia com o carecimento do qual ela remonta" ${ }^{23}$

Com efeito, em $A$ diferença dos sistemas de filosofia de Fichte e Schelling, também conhecido como Escrito sobre a diferença, de 1801, Hegel retoma o conceito kantiano de forma própria num momento em que pretende determinar o que é a filosofia, qual é a sua tarefa e qual é a sua relação com a história e com sua própria história. A carência, que em Kant emergia como uma característica transcendental da razão enquanto faculdade subjetiva, aparece agora como um dado histórico, inserido no tempo e no espaço. Não se trata mais da carência da razão, mas da carência da filosofia; em seu duplo genitivo: tanto aquilo do que a filosofia carece, quanto a carência que se tem da filosofia. Como em Kant, se trata ainda de uma carência por completude, por estabelecer uma vez mais a síntese do que é experimentado como separado ou como antitético, mas Hegel vê isso a que se aspira superar como um dado histórico: "A cisão (Entzweiung) é a fonte da carência da filosofia e, enquanto cultura da era, é o lado não livre e dado da figura". ${ }^{24}$

\footnotetext{
${ }^{21}$ BECKENKAMP, Joãosinho. O jovem Hegel: Formação de um sistema pós-kantiano. São Paulo: Loyola, 2009, p. 194.

${ }^{22}$ BECKENKAMP, Joãosinho. O jovem Hegel, op. cit., p. 39. Cf., ainda, numa apropriação romântica do conceito, a seguinte passagem do fragmento Hyperions Jugend (A juventude de Hyperion), de Hölderlin: "Sei que apenas a carência nos insta a dar à natureza uma semelhança com o que há de imortal em nós e a crer num espírito na matéria, mas eu sei que essa carência nos autoriza a isso (...)." (HÖLDERLIN, Friedrich. Sämtliche Werke. Bd. 3 (= Hyperion). Stuttgart: Kohlhammer, 1957, p. 192).

${ }^{23}$ CRISSIUMA, Ricardo. Será mesmo que a revolução terminou? Filosofia, crítica e história nos primeiros escritos hegelianos de Iena (1801-1802). Dissertação (Mestrado). Faculdade de Filosofia, Letras e Ciências Humanas. Departamento de Filosofia, Universidade de São Paulo. São Paulo, 2010, p. 13.

${ }^{24}$ HEGEL, G.W.F. Differenz des Fichteschen und Schellingschen Systems der Philosophie. In: Jenaer Schriften 1801-1807 (= Werke 2). Hrsg. E. Moldenhauer und K. M. Michel.

Frankfurt a.M.: Suhrkamp, 1986a, p. 20.
} 
A modernidade não é o primeiro momento histórico em que uma cisão põe em cena a carência da filosofia. A emergência enfática da filosofia, a cada vez que se deu na história, foi antes índice de tal carência provocada pela cisão. Mas de que cisão, afinal, se trata? Hegel vê a cultura ou formação (Bildung) de seu tempo como marcada pela hipertrofia (aos olhos de hoje, ainda incipiente) do assim chamado entendimento em detrimento da razão, seja no desenvolvimento das ciências que hoje chamamos formais, empíricas ou positivas, seja na transformação da estrutura econômica, social e política a partir da introdução da propriedade privada e do trabalho livre. ${ }^{25} \mathrm{Em}$ todos esses processos se vê em curso, aos olhos de Hegel, a atividade do entendimento, atividade analítica de conceituação do ente, de demarcação de limites, separação de funções, fixação de contraposições e enrijecimento de particularidades. É também o caso da filosofia kantiana: se ela teria operado, por exemplo, na dedução das categorias do entendimento, de modo fortemente especulativo, avançando pela razão até a identidade de sujeito e objeto, ou seja, até a superação da cisão mais fundamental, teria, por outro lado, retrocedido para manter essa mesma cisão intocada ao hipostasiar a coisa em si e fincar um abismo entre ela e os fenômenos; cisão que repercute, por exemplo, nas antinomias da dialética transcendental e na acima tratada separação entre uma razão teórica e uma razão prática. Em Kant, diz Hegel, "se o entendimento foi tratado com a razão, por outro lado a razão é tratada com o entendimento" ${ }^{26} \mathrm{O}$ entendimento é essa "força do limitar", que cinde a realidade e faz emergir a carência da filosofia, ou seja, a carência da atividade especulativa e sintética da razão em vista de um absoluto.

Como Hegel a compreende, essa "harmonia despedaçada" é produção espontânea da "originalidade viva do espírito", ${ }^{27}$ que, sendo ele mesmo absoluto, se manifesta, todavia, como cisão e alienação na cultura. Nela, a cisão se autonomiza e se enrijece, ganhando a aparência de não ter mais nada em comum com aquele absoluto que lhe precede e condiciona. Se, em Kant, a razão saía em busca de um incondicionado sem nunca poder encontrá-lo em definitivo, essa busca infrutífera parece caracterizar, em Hegel, antes a atividade do entendimento. $\mathrm{O}$ entendimento, ao mesmo tempo em que demarca limites e separações, põe-se também a buscar essa totalidade de limitações. E, de fato, a encontra (Hegel parece estar pensando justamente na obra kantiana), mas essa totalidade de limitações ainda é diferente do absoluto. Pois, quando encontra o incondicionado,

\footnotetext{
${ }^{25} \mathrm{Na}$ Filosofia do Direito, Hegel caracterizaria a sociedade civil-burguesa como um "Estado do entendimento" (Verstandsstaat) (HEGEL, G.W.F. Grundlinien der Philosophie des Rechts. Hrsg. von Horst Brand. Hamburg: Felix Meiner, 2013, § 183, p. 182; trad., p. 16).

${ }^{26}$ HEGEL, G.W.F. Differenz des Fichteschen und Schellingschen Systems der Philosophie, op. cit., p. 10.

${ }^{27}$ HEGEL, G.W.F. Differenz des Fichteschen und Schellingschen Systems der Philosophie, op. cit., p. 20.
} 
o ilimitado, o infinito, é a cada vez em oposição a um condicionado, um limitado, um finito, e, desse modo, a cada vez condicionado por uma oposição a partir da qual ele vem a se determinar, negando, assim, justamente o seu caráter de incondicionado, ilimitado ou infinito. O entendimento é impelido a encontrar a totalidade das limitações que ele mesmo põe, mas, nessa totalidade, se vê ainda mais afastado do absoluto.

Na metáfora de Hegel, o entendimento interpõe uma construção, um edifício (Gebäude) entre os homens e o absoluto, um edifício constituído por uma totalidade de demarcações de limites. Esse edifício impede o livre movimento da vida, da razão em si, que se esforça então para escapar para a liberdade. A imagem do edifício do entendimento no qual a vida movente se vê inibida (befangen) não deixa de lembrar aquela outra, cunhada por Max Weber pouco mais de um século mais tarde, da "rija crosta de aço" (stahlhartes Gehäuse), com a qual o sociólogo descreveu o constrangimento (ou, como Lukács o leria, a reificação) dos percursos de vida e o estreitamento das suas possibilidades a partir da separação de esferas de valor e da tendência à universalização da ação social orientada a fins no capitalismo. ${ }^{28}$

Nesse contexto histórico de enrijecimento e bloqueio do movimento da vida do espírito pela sua compartimentalização e atomização, "quando o poder da unificação desapareceu da vida dos homens (...), surge a carência da filosofia". ${ }^{29}$ Seu surgimento é, portanto, contingente, mas, uma vez estando presente, dada a cisão, precisará necessariamente suprassumir a contraposições que se tornaram fixas: "espírito e matéria, alma e corpo, fé e entendimento, liberdade e necessidade" e, contemporaneamente a Hegel, "razão e sensibilidade, inteligência e natureza e, para o conceito universal, a subjetividade absoluta e a objetividade absoluta". "Suprassumir essas contraposições que se tornaram fixas", diz Hegel, "é o único interesse da razão" ${ }^{30}$

A carência da filosofia se apresenta, assim, como o pressuposto da filosofia. No entanto, a filosofia, que, em Hegel, almeja o absoluto, precisa começar consigo e de si mesma, sem pressupostos. O caráter da carência da filosofia é, então, paradoxal: "A carência da filosofia pode ser expressa como o seu pressuposto se à filosofia, que começa consigo mesma, deve ser feita uma espécie de átrio". ${ }^{31}$ A carência, assim, "adquire uma forma da

\footnotetext{
${ }^{28}$ WEBER, Max. A ética protestante e o "espírito" do capitalismo. Trad. J. M. M. de Macedo. São Paulo: Companhia das Letras, 2004, p. 165.

${ }^{29}$ HEGEL, G.W.F. Differenz des Fichteschen und Schellingschen Systems der Philosophie, op. cit., p. 22.

${ }^{30}$ HEGEL, G.W.F. Differenz des Fichteschen und Schellingschen Systems der Philosophie, op. cit., p. 21.

${ }^{31}$ HEGEL, G.W.F. Differenz des Fichteschen und Schellingschen Systems der Philosophie, op. cit., p. 24.
} 
reflexão", ao modo de "enunciados contraditórios". A carência refletida sobre si mesma põe o absoluto que deve ser prévio à cisão e que deve estar pressuposto para que dele se careça. Por outro lado, põe igualmente a cisão de "ser e não-ser, conceito e ser, finitude e infinitude", como justamente aquilo que engendra a carência. Tais enunciados contraditórios, o do absoluto e o da cisão, diz Hegel, precisam ser justificados, mas essa justificação ainda não é a própria filosofia, mas sim sua "investigação e fundamentação" (Ergründen und Begründen). Não apenas a carência, mas a também a conceituação da carência é uma espécie de átrio, o vestíbulo que leva à filosofia.

Enquanto Kant pensou a carência como atributo estrutural da razão como portada por entes finitos, fruto de uma espécie de contradição necessária e a-histórica entre a infinitude da razão e a finitude dos indivíduos dotados de razão, Hegel pensou-a como característica de seu tempo, efeito prático de eventos da época de transição histórica que ele mesmo vivia (o Escrito sobre a diferença é escrito poucos anos depois do término da Revolução Francesa e poucos anos antes da invasão napoleônica na Prússia). Em ambos os casos, trata-se de uma compreensão positiva de uma espécie peculiar e superior de carência, de uma carência espiritual, que também se satisfaz (para Kant, sempre apenas precariamente; para Hegel, possivelmente de fato) através de produções do espírito, discursivas: a metafísica (Kant) ou a filosofia em geral (Hegel). Marx inverterá o problema: a carência não mais justifica a filosofia, mas a filosofia justifica de modo ideológico a sua própria tentativa de satisfazer carências substitutivamente num mundo organizado como "sistema de carências" (Hegel), isto é, em que carências possuem um caráter socialmente funcional.

\section{I.3 O jovem Marx e a carência filosófica como ideologia}

No prefácio à segunda edição da Ciência da Lógica, escrito por Hegel dias antes de seu falecimento em 1831, o filósofo remete à ideia presente na obra de Aristóteles de que foi necessário ter surgido na história pela primeira vez o ócio, isto é, a liberação do trabalho por uma casta dominante, como condição para a atividade filosófica. Liberados das carências materiais, os homens veem-se confrontados com outra forma de carência, uma espécie de carência de segunda ordem. Para sentir-se impelido a pensar os "pensamentos puros", o espírito humano precisou ter chegado à "carência da carência já satisfeita da necessidade, da ausência de carência" ("das Bedürfnis des schon befriedigten Bedürfnisses der Notwendigkeit, der Bedürfnislosigkeit"). ${ }^{32}$

${ }^{32}$ HEGEL, G.W.F. Wissenschaft der Logik I (= Werke 5). Hrsg. E. Moldenhauer und K. M. Michel. Frankfurt a.M.: Suhrkamp, 1986b, p. 23; trad., p. 34. 
A satisfação das carências engendra uma segunda forma de carência, uma forma de carência pelo espiritual. É Marx, todavia, quem retirará todas as consequências da vinculação dessa forma de satisfação de carências, ou ainda, da satisfação dessa forma de carências, e das relações de dominação que se expressam numa determinada divisão do trabalho. Entre o desenvolvimento acabado da filosofia hegeliana, empenhada na superação da carência da filosofia tratada em sua juventude, e a crítica materialista endereçada pelo jovem Marx àquelas carências espirituais que considera típicas do atraso econômico e político alemão, têm-se como ponto de inflexão a conhecida crítica da religião levada a cabo por David Strauss e, principalmente, por Ludwig Feuerbach. E, de fato, o tratamento dado por Marx ao problema sofre um pequeno, mas significativo deslocamento na medida em que sua própria relação com Feuerbach também se altera, o que se nota entre a "Para a crítica da filosofia do direito de Hegel", publicado em fevereiro de 1844 no único volume dos Anais Franco-Alemães como uma introdução à inacabada crítica dessa obra hegeliana, e os manuscritos da Ideologia Alemã, de 1845-46.

É o próprio Marx quem retoma e se apropria da crítica feuerbachiana no início do breve ensaio escrito em fins de 43. Os entes supraterrenos representados nas religiões, em particular da religião cristã, são descobertos pela crítica como mera projeção invertida da essência do homem; essência, todavia, não realizada na terra. A religião é o "fundamento geral de consolação e justificação do mundo", sendo, ao mesmo tempo "expressão de" e "protesto contra" a sua "miséria real". ${ }^{33}$ As ideias religiosas funcionam como um sucedâneo ilusório de uma efetivação impedida de ter lugar na prática. Satisfaz-se pela ideia, e, portanto, de modo falso, algo cuja satisfação verdadeira teria de se dar materialmente; e a religião floresce tanto mais, portanto, quanto mais o mundo terreno está afastado destes ideais representados por ela.

A crítica da religião - que, como se verá, sem que se extrapole muito a literalidade do texto de Marx, pode ser considerada uma crítica do conteúdo idealista assumido pelas carências humanas em um contexto histórico - é tomada como "o pressuposto de toda crítica". ${ }^{34}$ Sua crítica é condição para a "crítica do direito" e para a "crítica da política", ${ }^{35}$ enquanto Marx não encontra, justamente mediante ainda essas duas críticas, aquele objeto de cuja crítica depende efetivamente a satisfação ora sub-rogada dessas carências, a economia política. Criticar a religião, ou a forma falsa de satisfação de carências que ela promove, é já criticar, "de modo mediado, (...) aquele mundo cujo aroma espiritual é a religião", ${ }^{36}$ pois põe a nu, de

${ }^{33}$ MEGA $^{2} 1.2$, pp. 170-1; trad., p. 145.

${ }^{34} \mathrm{MEGA}^{2}$ 1.2, p. 170; trad., p. 145.

${ }^{35}$ MEGA $^{2} 1.2$, p. 171; trad., p. 146.

${ }^{36}$ MEGA $^{2}$ 1.2, p. 170; trad., p. 145. 
modo duro e impiedoso, a urgência da modificação prática do mundo ou a necessidade de fazê-lo corresponder de fato aos ideais que dele brotam.

Com efeito, todo o restante do texto é dedicado à caracterização e ao imperativo de superação desse estar aquém de seus ideais que Marx toma por típico daquele contexto alemão. Um estar aquém que se caracteriza não apenas pelo atraso econômico e político do país em relação a outros países europeus, em particular à França e à Inglaterra, mas também pela sua posição avançada no que diz respeito à postulação filosófica desses ideais e da crítica desenvolvida pela filosofia. A cisão entre ser e dever-ser ou entre o que é efetivo e o que se apresenta como possível à consciência é tão mais pronunciada na Alemanha da década de 1840 na medida em que no primeiro aspecto ela se encontra aquém de seu tempo, nem sequer levada a reboque, e, no segundo, determina o que é o estado da arte e demarca, como uma espécie de vanguarda, a posição do presente histórico.

Se Marx enfatiza que "as carências dos povos são nelas mesmas os fundamentos últimos de sua satisfação", ${ }^{37}$ por outro lado, como nota Ruy Fausto, ele também distingue duas espécies de carências, que cumprem papéis distintos, porém relacionados; e a superação da forma idealista de satisfação de carências denunciada pela crítica da religião a partir de uma modificação prática do mundo depende da correta articulação das duas. No texto,

'Necessidades', ou carências (Bedürfnisse) se opõem a 'exigências do pensamento' (Forderungen des Gedankes). Mas se encontra também 'necessidades teóricas', para designar as exigências do pensamento, e então se opõem dois tipos de necessidades. As necessidades (ou carências) práticas parecem tanto mais importantes na Alemanha, porque lá, onde 'a vida prática é sem espírito' e a 'vida espiritual sem prática', a 'capacidade de emancipação geral' depende sempre da 'situação imediata', 'da necessidade material', das 'próprias cadeias'..$^{38}$

E, todavia, são as carências do pensamento ou as carências teóricas que encontram satisfação imediata e falsa, impedindo justamente a satisfação das carências práticas. Para Marx, tudo depende de compreender que ambas as carências só podem ser adequadamente satisfeitas se forem ambas satisfeitas. A pergunta se "serão as carências teóricas imediatamente carências práticas?" deve receber uma resposta negativa, mas, em particular, em razão da tentada identificação imediata. Carências teóricas e práticas precisam justamente saber a si mesmas enquanto tais e só podem se satisfazer pela mediação recíproca. "A teoria sempre só é efetivada num

\footnotetext{
${ }^{37}$ MEGA $^{2} 1.2$, p. 173; trad., p. 148.

${ }^{38}$ FAUSTO, Ruy. O galo e a coruja: A propósito de Para a Crítica da Filosofia do Direito de Hegel (Introdução) (1844), de Marx, e de algumas dificuldades originárias do projeto marxiano. Dois Pontos, 13 (1), 2016, p. 22, n. 17.
} 
povo na medida em que é a efetivação de suas carências", ${ }^{39}$ caso em que Marx parece estar se referindo às carências práticas, materiais.

E isso depende de uma crítica dúplice, tanto das ideias quanto da realidade que delas destoa: "A nação alemã tem, por isso, de ligar a sua história onírica às suas condições existentes e submeter à crítica não apenas essas condições existentes, mas, ao mesmo tempo, a sua continuação abstrata" ${ }^{40}$ Do mesmo modo como não é possível "suprassumir a filosofia sem realizá-la", tampouco é possível "realizar a filosofia sem suprassumi-la". ${ }^{41}$ A própria filosofia só permanece existindo enquanto dela se carece, na medida em que o mundo não corresponde a seu conceito. Mas o sentido de toda carência é a sua própria satisfação, e, referindo-se essa carência a algo no e do mundo, sua satisfação deve ser possível como algo prático. Há, assim, para o Marx de 44, um lugar positivo para a filosofia, e ela se distingue da religião na medida em que sabe de sua relação com as carências materiais. Diferentemente da religião, que se pereniza porque faz a satisfação de carências espirituais tomar o lugar das carências materiais perenemente insatisfeitas, uma filosofia consequente deveria ter por objetivo o seu próprio tornar-se obsoleta. Sua obsolescência coincide com o acontecimento da revolução, "que só pode ser a revolução de carências radicais". ${ }^{42}$

Na Ideologia Alemã, o tema da não-contemporaneidade do desenvolvimento histórico alemão volta a comparecer, mas, desta vez, operando sobre o deslocamento de perspectiva em relação a Feuerbach, para denunciar não a religião, mas toda a filosofia alemã, inclusive e principalmente suas mais recentes correntes críticas, jovem-hegelianas, como uma tal forma substitutiva de satisfação das carências práticas. "É claro que na Alemanha, um país onde ocorre apenas um desenvolvimento histórico grosseiro, esses desenvolvimentos intelectuais, essas patifarias transfiguradas e ineficazes, servem naturalmente como substituto para a falta de desenvolvimento histórico". ${ }^{43}$ A filosofia - inclusive em suas correntes sensualistas, empiristas etc., ou seja, as que Marx chamará nas "Teses sobre Feuerbach" de "todo o materialismo existente até agora" ${ }^{44}$ - é como que em bloco compreendida como idealista, e, por meio dessa primeira identificação, novamente identificada como ideologia. Filosofia, idealismo, ideologia. As formulações críticas dos jovens hegelianos são todas compreendidas por Marx como uma "exigência

\footnotetext{
${ }^{39}$ MEGA $^{2} 1.2$, p. 178; trad., p. 152.

${ }^{40}$ MEGA $^{2}$ 1.2, p. 175; trad., p. 150.

${ }^{41}$ MEGA $^{2} 1.2$, p. 176; trad., p. 150-151.

${ }^{42}$ MEGA $^{2} 1.2$, p. 178; trad., p. 153. Para uma abordagem não naturalista da noção de verdade ou falsidade das carências humanas no jovem Marx, cf. CHITTY, Andrew. The early Marx on needs. Radical Philosophy, 64, 1993, p. 23-31.

${ }^{43}$ MARX, Karl; ENGELS, Friedrich; WEYDEMEYER, Joseph. Die deutsche Ideologie: Artikel, Druckvorlagen, Entwürfe, Reinschriftenfragmente und Notizen zu I. Feuerbach und II. Sankt Bruno. Marx-Engels Jahrbuch 2003. Hrsg. von der Internationalen Marx-Engels-Stiftung. Berlim: Akademie, 2004, p. 7; trad., p. 29-30.

${ }^{44}$ MEW 3, p. 533; trad., p. 533.
} 
de transformar a consciência", "de interpretar o existente de outra maneira, quer dizer, de reconhecê-lo por meio de uma outra interpretação", ${ }^{45}$ mas não de mudar o mundo ele mesmo. Trata-se ali de reinterpretar o mundo para que ele possa permanecer o mesmo. E "o que importa", como reza a formulação até hoje polêmica da décima primeira tese, "é transformá-lo". ${ }^{46}$ Os distintos autores criticados pelo jovem Marx, de Hegel aos jovens hegelianos, ou descreveram o existente de forma mistificada como se o presente já fosse a cada vez a figura máxima de efetivação da razão, ou denunciaram o descompasso dessas formas idealizadas em relação ao real através de soluções igualmente idealistas, restritas ao plano da teoria e impotentes em face da obstinada resistência das condições reais. ${ }^{47}$ Em qualquer caso, apresentaram sempre propostas de satisfação substitutivas das carências práticas reais, numa espécie de erro categorial ideológico que reconcilia na teoria aquilo que só pode ser reconciliado no mundo, e cumprindo a função de manter o mundo em estado de irreconciliação. "A 'libertação'", insiste Marx, "é um ato histórico, e não um ato de pensamento". ${ }^{48}$

\section{A critica da carência ontológica}

Se Ruy Fausto estiver correto em dizer que "a Dialética Negativa está construída sobre o fundo do fracasso do projeto da Ideologia Alemã ${ }^{\prime \prime}{ }^{49}$ será porque ela está construída sobre o fracasso prático de toda a filosofia clássica alemã, que, poder-se-ia dizer, culmina negativamente nessa obra de Marx e na exigência da décima primeira tese. $E$, se o paralelo não se esgota na referência das primeiras frases da Dialética Negativa ao destino dessa tese, ${ }^{50}$ mas se estende à opção de Adorno por tomar como primeiro

\footnotetext{
${ }^{45}$ MEW 3, p. 20; trad., p. 84

${ }^{46}$ MEW 3, p. 535; trad., p. 535.

47 “Certa vez, um nobre homem imaginou que os seres humanos se afogavam na água apenas porque estavam possuídos pela ideia da gravidade. Se afastassem essa representação da cabeça, por exemplo, esclarecendo-a como uma representação supersticiosa, religiosa, eles estariam livres de todo e qualquer perigo de afogamento. Durante toda a sua vida combateu a ilusão da gravidade, de cujas danosas consequências todas as estatísticas lhe forneciam novas e numerosas provas. Aquele nobre homem era do tipo dos novos filósofos revolucionários alemães" (MEW 3, p. 13-14; trad., p. 524).

${ }^{48}$ MARX, Karl; ENGELS, Friedrich; WEYDEMEYER, Joseph. Die deutsche Ideologie, op. cit., p. 6; trad., p. 29.

${ }^{49}$ FAUSTO, Ruy. O galo e a coruja, op. cit., p. 13.

50 "A filosofia, que um dia pareceu ultrapassada, mantém-se viva porque se perdeu (versäumt ward) o instante de sua realização. O juízo sumário de que ela simplesmente interpretou o mundo e é ao mesmo tempo deformada em si pela resignação diante da realidade torna-se um derrotismo da razão depois que a transformação do mundo fracassa" (AGS 6, p. 15; trad. ADORNO, Theodor W. Dialética negativa, op. cit., p. 11). É interessante notar que a carência ontológica é designada, em passagem aqui já citada, como "índice de uma perda", Index eines Versäumten. O verbo versäumen significa algo como perder uma oportunidade, deixar de fazer algo, deixar algo passar, não aproveitar algo.
} 
objeto a carência que subjaz à ontologia fundamental heideggeriana, é porque de algum modo a situação de Heidegger repete historicamente aquela de Hegel e dos jovens hegelianos criticados por Marx, a da ressaca de mais um fluxo acelerado de modernização capitalista sobrepondo-se a uma cultura romântica e nostálgica. Assim, nas palavras de Paulo Arantes, outra vez era o caso de que

nos idos de trinta [do século XX], o provincianismo militante da ontologia fundamental oferecia uma imagem compensatória, elevada e etérea do "país clássico da não-contemporaneidade", como designava Bloch a Alemanha, incapaz de dar uma forma homogênea e unívoca à razão capitalista, ao contrário da Inglaterra e da França, em que a Revolução Burguesa vingara a sua hora e vez..$^{51}$

Para Adorno, a ontologia fundamental deve contar como prolongamento tardio da tradição anti-iluminista e restauradora alemã, e a carência à qual o pensamento heideggeriano atende é uma carência enraizada profundamente na formação e na educação alemãs..$^{52}$ Mas de que se trata, afinal, na carência ontológica? O curso Ontologia e Dialética é mais claro sobre o assunto. Adorno pensa não apenas na enorme sedução provocada pela filosofia heideggeriana e outras correlatas no ambiente acadêmico alemão, ${ }^{53}$ mas também em sua penetração em esferas bastante mais prosaicas da vida: a questão é saber o que lhe dá esse "apelo da transcendência alcançada" 54 e por que tantos "se sentem tão interpelados por essa filosofia", 55 saber

qual páthos tem essa assim chamada pergunta pelo ser; porque os homens se exaltam tão tremendamente por essa questão do ser; e por que essa coisa se tornou eficaz de tal modo que termos como situatividade (Befindlichkeit), situação (Situation) e tantas outras quantas sejam essas palavras se rebaixaram quase até a esfera de anúncios de rádio e propaganda de pasta de dente..$^{56}$

O êxito da ontologia fundamental deve-se, para Adorno, à sua pretensão de retomar certas questões que, ao menos desde Kant, ou foram banidas do conjunto de assuntos que encontram lugar na divisão do trabalho da instituição filosófica universitária ou foram redescritas de forma asséptica e inofensiva no seu interior. Trata-se da pretensão de imediatez da reflexão filosófica à condução da vida pessoal, o sentimento de que a filosofia diz respeito efetivamente à singularidade daquele que se põe a pensar. A es-

\footnotetext{
${ }^{51}$ ARANTES, Paulo. Ressentimento da dialética: Dialética e experiência intelectual em Hegel. Rio de Janeiro: Paz e Terra, 1996, p. 349.

${ }^{52}$ ADORNO, Theodor W. Ontologie und Dialektik, op. cit., p. 148-150.

${ }^{53}$ Para Adorno, não é passível de dúvidas de que "uma tal carência existe, e existe também justamente entre jovens intelectuais, e sempre surgindo novamente com cada nova geração que tenha crescido nos últimos 40 anos ou mais [ou seja, ao menos desde 1920]" (ADORNO, Theodor W. Ontologie und Dialektik, op. cit., p. 146).

${ }^{54}$ AGS 6, p. 114; trad. ADORNO, Theodor W. Dialética negativa, op. cit., p. 98.

${ }_{55}$ ADORNO, Theodor W. Ontologie und Dialektik, op. cit., p.150.

${ }^{56}$ ADORNO, Theodor W. Ontologie und Dialektik, op. cit., p.16.
} 
pecialização universitária torna a filosofia abstrata, distante e inacessível a quem não possui formação filosófica, e a filosofia perde, assim, justamente aquilo em razão de que ela é feita. $\mathrm{O}$ abandono da possibilidade mesma de pensar as questões metafísicas no interior da filosofia departamentalizada, dado pelo "veredicto kantiano sobre o saber do absoluto", ${ }^{57}$ mantém perenemente insatisfeita a carência pelo absoluto. É essa a situação da qual Heidegger pode tirar proveito. Pois, protegido no interior da instituição filosófica e de sua especialização, Heidegger se dirige justamente às carências cuja impossibilidade de satisfação, ainda que apenas num plano intelectual, é corroborada pela própria forma universitária assumida pela filosofia. As ontologias, diz Adorno, "estabeleceram academicamente o páthos do não-acadêmico", ${ }^{58}$ e esse é o lugar privilegiado de onde podem dirigir-se à carência filosófica mais candente de seu tempo.

Mas, se na reflexão de Hegel em seu tempo a carência histórica por uma filosofia em particular era o índice de sua autenticidade, de sua afinidade com a universalidade de seu tempo, ${ }^{59}$ a demonstração de que tal filosofia é o "seu tempo apreendido em pensamentos", ${ }^{60} \mathrm{e}$, assim, a prova de sua verdade, a extensão dessa lógica à relação de Heidegger com seu tempo deve também levar em conta as transformações históricas materiais e a modificada relação entre teoria e prática, entre a filosofia e a sua realização, no capitalismo tardio. Pois se agora o endereçamento de Heidegger à carência ontológica, típica de seu tempo, e, reciprocamente, a "seleção" da filosofia heideggeriana por seu momento histórico, demonstrada por sua imensa repercussão, efetivamente são índices da adequação de Heidegger a seu contexto, isso diz ao mesmo tempo sobre os momentos de verdade e de falsidade da ontologia fundamental.

Num mundo em que a filosofia perdeu seu instante de realização - o que significa dizer, num mundo caracterizado pelo virtual alcance de uma situação de superação da escassez material através da produção abundante, não acompanhado, todavia, do fim da dominação então obsoleta - as carências não podem mais servir de critério para a determinação da verdade daquilo que as satisfaz. Trata-se de um mundo no qual é possível administrar e controlar o conteúdo das carências ao mesmo tempo em que se veda a sua satisfação, que se encontraria, todavia, à mão. Hegel e Marx já haviam reclamado a historicidade tanto do conteúdo das carências humanas quanto das formas de sua satisfação, algo que Adorno salienta também, de sua parte, de forma enfática. ${ }^{61} \mathrm{Em}$ Adorno, todavia, essa historicidade,

\footnotetext{
${ }^{57}$ AGS 6, p. 69; trad. ADORNO, Theodor W. Dialética negativa, op. cit., p. 59.

${ }^{58}$ AGS 6, p. 71; trad. ADORNO, Theodor W. Dialética negativa, op. cit., p. 60.

${ }^{59}$ HEGEL, G.W.F. Differenz des Fichteschen und Schellingschen Systems der Philosophie, op. cit., p. 24.

${ }^{60}$ HEGEL, G.W.F. Grundlinien der Philosophie des Rechts, op. cit., p. 18.

${ }^{61}$ AGS 8, p. 392; trad. ADORNO, Theodor W. Teses sobre a necessidade. In: . Ensaios sobre psicologia social e psicanálise. Trad. V. Freitas. São Paulo: UNESP, 2015, p. 229 ss.
} 
manifesta até então na mutabilidade do conteúdo da carência ao longo do desenvolvimento das forças produtivas, passa no capitalismo tardio por uma transformação qualitativa e se converte numa mutabilidade de forma. "A mediação social da carência - como mediação pela sociedade capitalista - alcançou um ponto onde a carência cai em contradição consigo mesma". ${ }^{62}$ As carências não apenas se modificam acompanhando a oferta de novas mercadorias ao consumo, mas modificam sua estrutura na medida em que são elas mesmas objeto de intervenção e seu conteúdo passa a poder ser induzido de modo técnico-científico. Subsumidas sob os imperativos de autovalorização da mercadoria no contexto administrado do capitalismo fordista, as carências não representam mais um momento de exterioridade, mesmo que mediada e residual, que pudesse determinar de algum modo o sentido da produção, mas se integram de modo tendencialmente total como momento determinado pelo processo produtivo.

Nas "Teses sobre a carência", de 1942, Adorno ainda precisa que "[a teoria da carência] não pode se colocar a priori nenhuma diferenciação entre carência boa e ruim, autêntica e fabricada, correta e falsa", de modo que as questões da carência devem ser reconhecidas a cada vez "em sua conexão concreta com a totalidade do processo social". ${ }^{63}$ Em sua fase tardia, todavia, Adorno é bem menos cauteloso e afirma a universalidade da administração das carências àquele estágio do desenvolvimento capitalista. Em "Capitalismo tardio ou sociedade industrial?", de 1968, afirma categoricamente que "para além de tudo o que era previsível por Marx em seu tempo, as carências, que há tempos existiam em potencial, se tornaram por completo funções do aparato produtivo, e não o contrário", sendo ora "totalmente dirigidas". Não se poderia mais contar com a "obviedade natural" do valor de uso das mercadorias, isto é, de sua relação com a satisfação das carências. ${ }^{64}$ No texto póstumo da Teoria Estética, Adorno afirma ainda:

A confiança nas carências dos homens que, com a intensificação das forças produtivas, levariam a totalidade a uma figura superior, deixa de ter sentido depois que as carências foram integradas e tornadas falsas pela sociedade falsa. Sem dúvida, tal como foi prognosticado, as carências encontram ainda a sua satisfação, mas esta, por sua vez, é falsa e defrauda os homens em seu direito humano. ${ }^{65}$

Não se devem ter dúvidas de que é no contexto desse diagnóstico de uma transformação na relação mesma entre carências e sua satisfação, sejam carências materiais ou espirituais, que a crítica a Heidegger e a sua eleição como primeiro objeto da dialética negativa deve ser compreendida. É a

\footnotetext{
${ }^{62}$ AGS 8, p. 393; trad. ADORNO, Theodor W. Teses sobre a necessidade, op. cit., p. 230.

${ }^{63}$ AGS 8, p. 393; trad. ADORNO, Theodor W. Teses sobre a necessidade, op. cit., p. 231.

${ }^{64}$ AGS 8, p. 361.

${ }^{65}$ AGS 7, p. 34-35; trad. ADORNO, Theodor W. Teoria estética. Trad. Artur Mourão. Lisboa: Edições 70, 2006, p. 30.
} 
atualização desse diagnóstico que torna possível recuperar implicitamente e de modo materialista a tematização da carência espiritual pela filosofia na filosofia clássica alemã. Se não em Kant, que trouxe à cena na modernidade o problema da carência da razão de dar unidade e completude à experiência, já então de modo tímido em Hegel e abertamente desenvolvido em Marx, a carência à qual a filosofia busca responder é igualmente uma carência material e determinada historicamente. A falsidade das carências integradas no capitalismo tardio, no contexto alemão da década de 1960, marca o essencial da retomada da crítica a Heidegger a partir desse lugar aparentemente exterior, o das carências que suscitam seu pensamento. "A própria carência, a carência espiritual não menos do que a material, é exposta à crítica depois que mesmo uma tenaz ingenuidade não pode confiar mais no fato de os processos reais ainda se orientarem pela oferta e demanda, e, com isso, pelas carências". ${ }^{66}$

Mas qual é a especificidade histórica da carência ontológica à qual a ontologia heideggeriana se adéqua tão bem? O que significa denominá-la uma carência ontológica? Trata-se do tipo de carência suscitada por uma mediação tendencialmente total do indivíduo pela sociedade, e "a ontologia e a filosofia do ser" respondem a essa carência na medida em que são "modos de reação nos quais a consciência espera arrancar-se desse enredamento". ${ }^{67}$ Parece que estamos diante de desdobramentos daquele edifício erigido pelo entendimento, tratado pelo jovem Hegel, no interior do qual a vida se inquietava carecendo de uma síntese que levasse além da sua infinitesimal separação.

Na Alemanha da década de 1820, a confiança do tempo histórico na espontaneidade prática do sujeito, em sua capacidade de criar mundo e de moldá-lo racionalmente, levou o velho Hegel a responder à carência da filosofia antecipando no pensamento dialético uma superação da cisão na forma da reconciliação. Tal antecipação foi ideológica, como denunciou o jovem Marx, pois ofereceu uma reconciliação ideal como substituta da reconciliação real, cristalizando e justificando a cisão real. Tendo em mente o Hegel maduro, Adorno sentenciou que "a antecipação filosófica da reconciliação atenta contra a reconciliação real" ${ }^{68}$ Uma invectiva semelhante é dirigida a Heidegger: "A nênia sobre o esquecimento do ser é uma sabotagem da reconciliação"; "69 mas a diferença daquilo que Adorno visa com cada uma das objeções demarca a especificidade da carência ontológica. Pois o sentimento de potência subjetiva e a confiança na razão em conformar o mundo, características do século que se segue à Revolu-

\footnotetext{
${ }^{66}$ AGS 6, p. 99; trad. ADORNO, Theodor W. Dialética negativa, op. cit., p. 85.

${ }^{67}$ AGS 6, p. 75; trad. ADORNO, Theodor W. Dialética negativa, op. cit., p. 65.

${ }^{68}$ AGS 5, p. 273; trad. ADORNO, Theodor W. Três estudos sobre Hegel. Trad. U. R. Vaccari. São Paulo: UNESP, 2013, p. 102.

${ }^{69}$ AGS 6, p. 99; trad. ADORNO, Theodor W. Dialética negativa, op. cit., p. 85.
} 
ção Francesa e à imposição política da dominação econômica burguesa, isto é, aos tempos de Hegel, cedem lugar já após as primeiras décadas no século XX ao seu contrário. A carência ontológica corre em paralelo a um sentimento de impotência, reflexo da impotência real dos indivíduos num mundo no qual a condução administrada dos processos sociais torna os indivíduos antes objetos para a intervenção de uma razão reduzida à técnica. Trata-se, neste mundo no qual o indivíduo sente estar à deriva, submisso a uma força maior, de uma "carência de um ponto de apoio, de algo supostamente substancial". ${ }^{70}$ "A mais urgente de suas carências hoje parece a carência de algo firme". ${ }^{71}$

Note-se, portanto, as distintas posturas filosóficas, segundo Adorno, que Hegel e Heidegger assumem em relação à reconciliação, isto é, àquilo que representaria uma efetiva superação da cisão, portanto, uma efetiva satisfação da carência em geral. Enquanto Hegel a anteciparia em seu sistema filosófico onde tudo se encontra reconciliado no saber absoluto, que retroage santificando a realidade social ainda cindida, Heidegger antes lamentaria melancolicamente um suposto esquecimento do ser como algo originário, ora soterrado por camadas de sentido historicamente sedimentadas que lhe impediriam o acesso e necessitariam ser destruídas. Enquanto em Hegel preserva-se ao menos o excedente do sistema filosófico em relação ao mundo que ele pretende apreender, assim como a noção de que não é possível simplesmente retornar a um estado originário anterior à cisão (pois um tal estado não há), mas ela precisa ser superada em seu próprio interior, Heidegger antes abdica de tal possibilidade e advoga por um retorno ao ser como algo prévio tanto lógica quanto historicamente ao sentido de todo ente, a toda conceitualidade e, portanto, à cisão fundamental de sujeito e objeto. Heidegger não responde à carência engendrada pela cisão tentando ir além da cisão, mas antes se postulando a tarefa de desfazê-la para acessar o ser originário. Mesmo que muito sumariamente, deve-se compreender, todavia, como Heidegger pretende fazê-lo, a fim de demonstrar sua afinidade com a carência ontológica em seus momentos de verdade e de falsidade.

Diferentemente de outros projetos ontológicos de seu tempo (e de alguns do nosso), a ontologia fundamental heideggeriana não visou suspender a validade do giro copernicano de Kant e postular ingenuamente um acesso imediato às coisas ou aos entes. Ao mesmo tempo, com a ambiguidade do conceito de ser, Heidegger qualifica a sua filosofia como ontológica num sentido sofisticado, que se apresenta como um desafio contemporâneo. A experiência do ser, para Heidegger, seria a mais originária, prévia à experiência dos entes. Não se trata de acessar diretamente o ente, mas o ser, o qual não poderia ser acessado de outro modo. O ser do ente sempre

${ }^{70}$ AGS 6, p. 102; trad. ADORNO, Theodor W. Dialética negativa, op. cit., p. 88.

${ }^{71}$ AGS 6, p. 100; trad. ADORNO, Theodor W. Dialética negativa, op. cit., p. 86. 
excede o ente individualizado no espaço e no tempo, e isso é o que Heidegger chama de "diferença ontológica". O ser possui essa característica na medida em que está para além de toda conceitualidade. Para Heidegger, ser não é um conceito. Não há transição possível entre um conceito e o ente por ele conceituado, ou entre o conceito de algo e o fato de que esse algo é: o ser é experimentado diretamente, de forma não-mediada. Ao mesmo tempo, o conceito de ser, não é o ser ele mesmo, mas, justamente, um conceito. O ser é o conceito do não-conceitual, um esforço por falar daquilo que não pode ser dito. O ser é, portanto, ao mesmo tempo o conceito por excelência, o conceito de tudo aquilo que é, e o não-conceito por excelência, aquilo que sempre escapa da conceitualidade e pretende ser experimentado diretamente. Para Adorno, todavia, Heidegger faz desse caráter aporético do conceito de ser uma prerrogativa para interromper a reflexão e agir como se com a palavra "ser" já estivéssemos de posse do excedente infinito por ela prometido." A intenção de apagar tudo isso por meio da regressão a um ponto anterior à reflexão do pensamento crítico em um tempo primevo sagrado", isto é, aos primórdios da reflexão da escola de Mileto, "não gostaria senão de contornar coações filosóficas que, uma vez reconhecidas, impediriam o apaziguamento da carência ontológica".$^{72}$

Vê-se, em todo caso, em que sentido a ontologia fundamental, orientada prima facie não à determinação do sentido dos entes, mas antes à determinação do sentido de ser dos entes, ${ }^{73}$ responde à carência de seu tempo. A "tentativa de irrupção" da cela da mediação total da conceitualidade em vista de uma fusão originária com o indeterminado ${ }^{74} \mathrm{com}$ o que simplesmente é, corre em paralelo e responde de modo puramente idealista (e, portanto, ideológico) ao sentimento de impotência e aprisionamento do sujeito no apogeu do capitalismo administrado. Mas, diz Adorno, "carências reais podem ser objetivamente ideologias, sem que precise surgir daí um direito de negá-las".$^{75}$ Ainda que não sejam verdadeiras, tais carências são reais. As respostas filosóficas talhadas segundo a carência ontológica se encontram no lugar ambíguo "entre o compromisso legítimo de oferecer pão e não pedras e a conviç̧ão ilegítima de que precisaria ser pão porque assim precisa ser". ${ }^{76}$ Uma postura teórica materialista deve tê-las em conta e, por sua crítica imanente, fazer valer seu momento de verdade. A carência

\footnotetext{
${ }^{72}$ AGS 6, p. 79; trad. ADORNO, Theodor W. Dialética negativa, op. cit., p. 68.

${ }^{73}$ Digo prima facie, pois, para Adorno, na determinação das estruturas formais do ser recuperadas a partir da indagação do Dasein, Heidegger termina por rigidificar também o plano dos entes, contrariando sua própria intenção expressa. Cf. a crítica adorniana da "ontologização do ôntico" (AGS 6, pp. 125-128, trad. ADORNO, Theodor W. Dialética negativa, op.cit., pp. 107-110; ADORNO, Theodor W. Ontologie und Dialektik, op. cit., p. 109-138.

${ }^{74}$ AGS 6, p. 94, trad. ADORNO, Theodor W. Dialética negativa, op. cit., p. 81; AGS 5, p. 193 ss., trad. ADORNO, Theodor W. Para a metacrítica da teoria do conhecimento: Estudo sobre Husserl e as antinomias fenomenológicas. Trad. M. A. Casanova. São Paulo: UNESP, 2015, p. 305 ss. ${ }^{75}$ AGS 6, p. 99, trad. ADORNO, Theodor W. Dialética negativa, op. cit., p. 86.

${ }^{76}$ AGS 6, p. 79, trad. ADORNO, Theodor W. Dialética negativa, op. cit., p. 68.
} 
ontológica e a noção heideggeriana de diferença ontológica representam negações abstratas e, portanto, adequadas àquilo que negam, isto é, à situação de mediação totalizante, seja pelo conceito, seja pelo valor, ou, poder-se-ia dizer especulativamente, talvez da solidariedade de ambos, no capitalismo tardio. Pois, como resta claro, a ontologia fundamental deixa intacto o mundo que provoca sua carência mobilizadora. "[Uma tal carência] pode ser tão pouco apaziguada por essa filosofia como podia outrora sê-lo pelo sistema transcendental". ${ }^{77}$ "A carência ontológica garante tão pouco o que quer quanto o tormento dos esfomeados lhes garante a ceia", pois "aquilo que o filosofar ontológico buscava como que despertar por conjuração é minado por processos reais, pela produção e reprodução da vida social" ${ }^{78}$

Operando como sucedâneos de carências verdadeiras e da satisfação verdadeira dessas carências, a carência ontológica e a ontologia fundamental oferecem ao dialético, ainda assim, um índice daquilo que substituem e que caberia enfrentar de modo consequente. Como o jovem Hegel, Adorno reconhece que "o pensamento sem carência, que não quer nada, seria nulo", mas com a ressalva de que "verdadeiro seria o pensamento que deseja algo correto".$^{79} \mathrm{~A}$ crítica da carência ontológica é um passo da complexa crítica imanente da ontologia fundamental e, inclusive, da própria formulação de uma dialética negativa, porque a partir dessa carência falsa e da especificidade da resposta filosófica que lhe atende é possível reter algo daquela carência verdadeira que deve mobilizar o pensamento, um momento que só pode ser compreendido como um negativo.

\section{Critica imanente, diferença ontológica e não-} identidade

Entre o curso Ontologia e Dialética, ofertado por Adorno no semestre de inverno de 1960/61, que pode ser compreendido como preparatório para a redação da Parte I ("Relação com a ontologia") da Dialética Negativa, e a redação definitiva desta, publicada em 1966, Adorno muda sua estratégia de exposição no que diz respeito ao lugar da crítica da carência ontológica. Ainda que se refira ao problema já na primeira aula do curso, a crítica da carência ontológica só vem a ser introduzida no décimo encontro, quando Adorno já tratara de temas que viriam a compor o capítulo "Ser e existência". O editor do curso, Rolf Tiedemann, registra a mudança na seguinte nota de rodapé: "Na relação do presente curso com a Dialética

77 AGS 6, p. 71; trad. ADORNO, Theodor W. Dialética negativa, op. cit., p. 61.

${ }^{78}$ AGS 6, p. 73, trad. ADORNO, Theodor W. Dialética negativa, op. cit., p. 62-63.

${ }^{79}$ AGS 6, p. 100; trad. ADORNO, Theodor W. Dialética negativa, op. cit., p. 86. 
Negativa, é característico que na última o primeiro capítulo se concentra justamente na análise da 'carência ontológica', enquanto as horas de curso ao menos até este momento contavam como 'considerações prévias'" 80 Ademais, enquanto no curso o problema da carência ocupa Adorno por cerca de duas das vinte e três aulas, no livro ele toma agora pouco mais da metade da sua Parte I.

O que representa essa mudança? E por que, tendo afirmado tanto no curso de 60/61 quanto no prefácio do livro de 66 que a crítica da carência ontológica faz parte da crítica imanente da ontologia fundamental, Adorno abre o capítulo "Ser e Existência" com a seguinte afirmação: "A crítica da carência ontológica conduz à crítica imanente da ontologia", ${ }^{81}$ como se até então ainda não estivéssemos no plano desta? Veja-se como Hegel caracteriza as reflexões iniciais sobre a carência da filosofia na "Lembrança prévia" do Escrito da diferença:

No que diz respeito às reflexões gerais sobre carência, pressuposto, princípios etc., com as quais esse escrito começa, elas possuem o defeito de serem reflexões gerais, e sua razão está em que a entrada na filosofia ainda é coberta de teias de aranha com tais formas como pressuposto, princípios etc., e, por isso, até um certo grau ainda é necessário se envolver com elas até que um dia só se fale de todo da própria filosofia. ${ }^{82}$

Seria este também o caso de Adorno? Tratando da carência ontológica, ainda estaríamos no pórtico à crítica imanente da ontologia fundamental? Mas por que Adorno dissera o contrário? E por que isso que no livro ocuparia esse lugar de pórtico era antes introduzido apenas tardiamente no argumento contra Heidegger? O que significaria estar "fora" para uma filosofia deliberadamente antissistemática, como a dialética negativa? Essa dificuldade na interpretação do texto tem algo a contribuir à determinação do sentido de crítica imanente em Adorno?

Como salienta Jürgen Naeher, "na crítica da carência, o primeiro capítulo ainda não começa primariamente com o ímpeto da 'própria força' do adversário", mas sim "com a força do efeito desse adversário, com a força da recepção" ${ }^{83} \mathrm{O}$ quão distante estamos de uma crítica imanente, isto é, de uma crítica que acompanha os desdobramentos lógicos do próprio objeto, compreendendo-o melhor do que ele mesmo se compreende? Voltemos à apresentação do curso de 60/61, onde Adorno afirmara que a crítica imanente da ontologia parte da carência ontológica. Ali, logo em seguida,

\footnotetext{
${ }^{80}$ Nota do editor em ADORNO, Theodor W. Ontologie und Dialektik, op. cit., p. 368, n. 103.

${ }^{81}$ AGS 6, p. 104; trad. ADORNO, Theodor W. Dialética negativa, op. cit., p. 90.

${ }^{82}$ HEGEL, G.W.F. Differenz des Fichteschen und Schellingschen Systems der Philosophie, op. cit., p. 13-14.

${ }^{83}$ NAEHER, Jürgen. Das ontologische „Bedürfnis im Denken“: Der Erste Teil der Negativen Dialektik (67-136). Zum Verfahren der ,immanenten Kritik'. In:

Dialektik Adornos. Opladen: Leske und Budrich, 1984, p. 214. (Hrsg.). Die Negative
} 
referindo-se ao primeiro livro da Ciência da Lógica de Hegel, mas também à "situação contemporânea", Adorno afirma que "a dialética é, então, o fato de que a transição à dialética deve consistir propriamente na autorreflexão crítica da ontologia; ou, para exprimi-lo novamente de modo hegeliano, a dialética é mediada em si exatamente pela ontologia" ${ }^{84} \mathrm{~A}$ dialética não é caracterizada de modo hipostasiado, não é "fixada como uma estrutura portadora", ${ }^{85}$ mas é antes apresentada como o próprio processo de crítica imanente da ontologia, ou seja, de toda tentativa de apresentar filosoficamente o ente de modo desistoricizado e fechado numa identidade. Faz sentido, portanto, que a Dialética Negativa tenha início com uma crítica da ontologia fundamental, isto é, da ontologia em sua figura adequada a seu tempo e às suas carências e à altura do desenvolvimento filosófico. Mas, ainda, por que esse início não se dá diretamente com a crítica da própria ontologia, mas sim com a crítica da carência ontológica?

Para uma filosofia que se entende como "antissistema", isto é, uma que, "com meios logicamente consistentes", "se esforça por colocar no lugar do princípio de unidade e do domínio totalitário do conceito supraordenado a idéia daquilo que estaria fora do encanto de tal unidade", ${ }^{86}$ as noções de "dentro" e "fora" precisam ser revisitadas. Já para a dialética hegeliana, a relação entre imanência e transcendência deixa de ser disjuntiva: "trata-se de uma recaída na lógica tradicional, criticada na polêmica de Hegel contra Kant: todo e qualquer método que determina limites e se mantém dentro dos limites de seu objeto suplanta, por isso mesmo, esses limites". ${ }^{87}$ Apesar de manter esse ganho da posição hegeliana, a reformulação negativa da dialética implica numa inversão da relação. Ela se põe reflexivamente a par também dos limites da crítica que se atém aos limites do objeto. "A crítica imanente tem seus limites no fato de que, por fim, a lei do nexo de imanência se confunde com a ofuscação que seria preciso quebrar". ${ }^{88}$ Uma formulação ingênua da noção de crítica imanente se confundiria com a afirmação de um conceito positivo ao qual o objeto não corresponderia. A crítica proposta pela dialética negativa não tem por télos uma identificação, mas antes o contrário. "A identidade pura é aquilo que é posicionado pelo sujeito, e, nessa medida, algo trazido de fora. Por isso, de maneira bastante paradoxal, criticá-la imanentemente significa criticá-la de fora" ${ }^{89}$ Como em Hegel, portanto, a disjunção de imanência e transcendência é mantida, mas ela é posta de ponta-cabeça.

\footnotetext{
${ }^{84}$ ADORNO, Theodor W. Ontologie und Dialektik, op. cit., p. 12-13.

${ }^{85}$ AGS 6, p. 140; trad. ADORNO, Theodor W. Dialética negativa, op. cit., p. 120.

${ }^{86}$ AGS 6, p. 10; trad. ADORNO, Theodor W. Dialética negativa, op. cit., p. 8.

${ }^{87}$ AGS 10.1, p. 25-26; trad. ADORNO, Theodor W. Crítica cultural e sociedade. In:

Prismas: Crítica cultural e sociedade. Trad. A. Wernet e J. de Almeida. São Paulo: Ática, 1998, p. 21-22.

${ }^{88}$ AGS 6, p. 183; trad. ADORNO, Theodor W. Dialética negativa, op. cit., p. 157.

${ }^{89}$ AGS 6, p. 149; trad. ADORNO, Theodor W. Dialética negativa, op. cit., p. 127.
} 
Para não apenas se manter afirmativamente no interior do objeto, mas também criticá-lo, é preciso ter já transcendido sua instanciação atual. "Sem essa liberdade, sem o transcender da consciência para além da imanência cultural, a própria crítica imanente não seria concebível: só é capaz de acompanhar a dinâmica própria do objeto aquele que não estiver completamente envolvido por ele".$^{90}$

Fora e dentro do objeto criticado, pórtico de entrada e antecipação de resultados, a carência ontológica que engendra e sustenta a ontologia heideggeriana ao mesmo tempo conduz à crítica imanente desta e conjectura o seu momento de verdade. A crítica da carência denuncia o seu conteúdo falso, como uma carência por solidez, firmeza, segurança, em outras palavras, como um anseio pelo retiro abdicado de um mundo no qual a ação humana se tornou impotente. A ontologia fundamental lhe é afim na medida em que renuncia à reflexão, à superação das contradições do mundo, e postula falsamente um acesso imediato a um ser originário, capaz de reconfigurar o sentido dos entes. À parte os conteúdos positivos da carência e da sua pseudossatisfação filosófica, o que resta, no entanto, ainda que como um puro negativo, é a necessidade de que alguma carência, isto é, alguma falta, um algo que anseia por satisfação, irrompa num mundo em que a mediação da sociabilidade pareceu ter se tornado total. A carência denuncia a falsidade da totalidade, pois, numa situação de integração social realmente total, a carência não seria sequer sentida. Se o conteúdo da carência é falso, o fato de que ela é sentida pode ser jogado contra o modo falso como ela tenta se satisfazer.

A solução heideggeriana indica, assim, um passo para uma reformulação negativa da dialética, isto é, de uma dialética da não-identidade. Se for correto afirmar a centralidade da noção de diferença ontológica no projeto heideggeriano como um todo, vê-se como o conceito igualmente central para Adorno de não-identidade - conceito que é como que o ponto de fuga da Parte II, seguinte, da Dialética Negativa - assoma como retenção do momento de verdade da ontologia fundamental. ${ }^{91}$ Não se

\footnotetext{
${ }^{90}$ AGS 10.1, p. 23; ADORNO, Theodor W. Crítica cultural e sociedade, op. cit., p. 19. Sem constituir a regra na tradição dialética, a inversão é, todavia, de algum modo prefigurada na Fenomenologia do Espírito, na distinção metodológica entre o ponto de vista da consciência que acompanha cada figura do movimento da experiência, e o ponto de vista do filósofo já detentor do saber absoluto, que irrompe ocasionalmente na narrativa desse movimento antecipando um resultado; do mesmo modo, na distinção marxiana entre o modo de investigação e o de exposição n'O Capital. Nos dois casos, apenas porque o dialético já transcendeu uma determinada figura ou estágio da apresentação fora e antes da apresentação é que se torna possível ultrapassar essa figura ou estágio de modo imanente.

${ }_{91}$ Para uma reflexão que visa "compreender a crítica de Adorno a Heidegger a partir da sua convergência", cf. NEVES SILVA, Eduardo S. Adorno, Heidegger, metafísica e ontologia. In: PUCCI, B.; FRANCO, R.; GOMES, L. R. (orgs.). Teoria crítica na era digital: Desafios. São Paulo: Nankin, 2014, p. 217-224.
} 
tratará mais de pensar a diferença entre o ser do ente e o próprio ente como estrutura do ser, pois, para Adorno, não há ser do ente em geral, mas apenas o ente conceituado e relacionado a cada vez em um juízo que o identifica. Aquilo que Heidegger visa com o conceito ontológico de ser é pensado por Adorno pelo conceito refletido de não-identidade, o que impede aquela satisfação imediata e quasi-mística da carência no acesso a um suposto ser, mas torna necessária a paciência e o esforço conceitual como forma refletida de reter o caráter não idêntico do pensado. Como aponta também Naeher, "Adorno reprova na mais recente fenomenologia, principalmente na ontologia, o fato de que ela procura satisfazer essa carência em vez de lê-la como uma remissão a algo que falta (auf ein Fehlendes), a algo de negativo (auf Negatives), e, enquanto tal, retê-la reflexivamente" ${ }^{92}$ É saldo da crítica marxiana a Hegel e aos jovens hegelianos que a carência não pode ser satisfeita por meios espirituais. Para Adorno, igualmente, não se trata de oferecer outra forma de satisfação filosófica. Não é essa a tarefa que cabe à filosofia. Heidegger teria buscado uma impossível fuga ao não-conceitual como forma de satisfação. Para Adorno, se trata de insistir em "abrir o não-conceitual com conceitos", ${ }^{93}$ se isso também for possível. A partir daí tem-se toda a formulação de uma dialética negativa.

\section{Referências}

ADORNO, Theodor W. Gesammelte Schriften: in 20 Bänden. Hrsg. R. Tiedemann. Frankfurt a.M.: Suhrkamp, 1997. (Citado segundo a convenção: AGS + número do volume, seguido, quando for o caso, da referência das traduções consultadas).

Traduções consultadas:

ADORNO, Theodor W. Crítica cultural e sociedade. In: Prismas: Crítica cultural e sociedade. Trad. A. Wernet e J. de Almeida. São Paulo: Ática, 1998, pp. 7-26. ADORNO, Theodor W. Teoria estética. Trad. Artur Mourão. Lisboa: Edições 70, 2006. ADORNO, Theodor W. Dialética negativa. Trad. M. A. Casanova. Rev. E. S. N. Silva. Rio de Janeiro: Zahar, 2009.

ADORNO, Theodor W. Três estudos sobre Hegel. Trad. U. R. Vaccari. São Paulo: UNESP, 2013.

${ }_{92}^{2}$ NAEHER, Jürgen. Das ontologische „Bedürfnis im Denken“, op. cit., p. 213.

${ }^{93}$ AGS 6, p. 21; ADORNO, Theodor W. Dialética negativa, op. cit., p. 17. 
ADORNO, Theodor W. Para a metacrítica da teoria do conhecimento: Estudo sobre Husserl e as antinomias fenomenológicas. Trad. M. A. Casanova. São Paulo: UNESP, 2015.

ADORNO, Theodor W. Teses sobre a necessidade. In: Ensaios sobre psicologia social e psicanálise. Trad. V. Freitas. São Paulo: UNESP, 2015, pp. 229-235.

ADORNO, Theodor W. Ontologie und Dialektik (1960/61). Hrsg. R. Tiedemann. Frankfurt a.M.: Suhrkamp, 2002.

ARANTES, Paulo. Ressentimento da dialética: Dialética e experiência intelectual em Hegel. Rio de Janeiro: Paz e Terra, 1996.

BECKENKAMP, Joãosinho. O jovem Hegel: Formação de um sistema pós-kantiano. São Paulo: Loyola, 2009.

CHITTY, Andrew. The early Marx on needs. Radical Philosophy, 64, 1993, p. 23-31.

CRISSIUMA, Ricardo. Será mesmo que a revolução terminou? Filosofia, crítica e história nos primeiros escritos hegelianos de Iena (1801-1802). Dissertação (Mestrado). Faculdade de Filosofia, Letras e Ciências Humanas. Departamento de Filosofia, Universidade de São Paulo. São Paulo, 2010.

FAUSTO, Ruy. O galo e a coruja: A propósito de Para a Crítica da Filosofia do Direito de Hegel (Introdução) (1844), de Marx, e de algumas dificuldades originárias do projeto marxiano. DoisPontos, 13 (1), 2016, p. 3-28.

GANDESHA, Samir. Leaving Home: On Adorno and Heidegger. HUHN, Tom (ed.). The Cambridge Companion to Adorno. Cambridge, UK: Cambridge UP, 2004, p. 101-128.

HEGEL, G.W.F. Differenz des Fichteschen und Schellingschen Systems der Philosophie. In: Jenaer Schriften 1801-1807 (= Werke 2). Hrsg. E. Moldenhauer und K. M. Michel. Frankfurt a.M.: Suhrkamp, 1986a, p. 7-138.

HEGEL, G.W.F. Wissenschaft der Logik I (= Werke 5). Hrsg. E. Moldenhauer und K. M. Michel. Frankfurt a.M.: Suhrkamp, 1986b (Tradução consultada: Ciência da Lógica: 1. A doutrina do ser. Trad. Ch. Iber, M. Miranda e F. Orsini. Petrópolis: Vozes, 2016.)

HEGEL, G.W.F. Grundlinien der Philosophie des Rechts. Hrsg. von Horst Brand. Hamburg: Felix Meiner, 2013. (Tradução parcial consultada: HEGEL, G.W.F. Linhas fundamentais da Filosofia do Direito ou Direito Natural e Ciência do Estado em Compêndio. Terceira Parte: A Eticidade. Segunda Seção: A Sociedade Civil. Tradução, introdução e notas de M. L. Müller. Clássicos da Filosofia: Cadernos de Tradução n. 6, Campinas: IFCH/UNICAMP, 2003.)

HÖLDERLIN, Friedrich. Sämtliche Werke. Bd. 3 (= Hyperion). Stuttgart: Kohlhammer, 1957.

KANT, Immanuel. Gesammelte Schriften. Hrsg.: Bd. 1-22 Preussische Akademie der Wissenschaften, Bd. 23 Deutsche Akademie der Wissenschaften zu Berlin, ab Bd. 24 Akademie der Wissenschaften zu Göttingen. Berlim: Walter de Gruyter, 1900ff. 
Citado segundo a convenção:

$\mathrm{KrV}$ A - Kritik der reinen Vernunft, 1a. ed., de 1781 (AA 04)

KrV B - Kritik der reinen Vernunft, 2a. ed., de 1787 (AA 03)

Tradução consultada: Crítica da Razão Pura. Trad. F. C. Mattos. Petrópolis: Vozes, 2012.

$\mathrm{KpV}$ - Kritik der praktischen Vernunft (AA 05)

Tradução consultada: Crítica da razão prática. Trad. M. Hulshof. Petrópolis, Vozes, 2016.

WDO - „Was heißt: sich in Denken orientieren?“ (AA 08)

Tradução consultada: “O que quer dizer: orientar-se no pensamento?" Trad. Joãosinho Beckenkamp. In: BECKENKAMP, Joãosinho. Entre Kant e Hegel. Porto Alegre: EDIPUCRS, 2004, p. 21-39.

KLEIN, Joel. Sobre o significado e a legitimidade transcendental dos conceitos de precisão, interesse, esperança e crença na filosofia kantiana. Veritas, 59, 1, 2014, p. 143-173.

MARX, Karl; ENGELS, Friedrich. Marx-Engels Werke. Bd. 3 (= Die deutsche Ideologie). Berlim: Dietz, 1978. Citado segundo a convenção: MEW 3.

MARX, Karl; ENGELS, Friedrich; WEYDEMEYER, Joseph. Die deutsche Ideologie: Artikel, Druckvorlagen, Entwürfe, Reinschriftenfragmente und Notizen zu I. Feuerbach und II. Sankt Bruno. Marx-Engels Jahrbuch 2003. Hrsg. von der Internationalen Marx-Engels-Stiftung. Berlim: Akademie, 2004.

(Tradução consultada para as duas edições parciais de Die deutsche Ideologie: MARX, Karl, ENGELS, Friedrich. A ideologia alemã: Crítica da mais recente filosofia alemã em seus representantes Feuerbach, B. Bauer e Stirner, e do socialismo alemão em seus diferentes profetas. Trad. R. Enderle, N. Schneider e L. Martorano. São Paulo: Boitempo, 2007.)

MARX, Karl. Zur Kritik der Hegelschen Rechtsphilosophie. In: MARX, Karl; ENGELS, Friedrich. Marx-Engels Gesamtausgabe. 1. Abt. Bd. 2. Berlim: Dietz, 1982, pp. 170-183. Citado segundo a convenção: MEGA² 1.2 (Tradução consultada: Crítica da filosofia do direito de Hegel - Introdução. In: MARX, Karl. Crítica da filosofia do direito de Hegel. 2a. ed., rev. Trad. R. Enderle e L. de Deus. São Paulo: Boitempo, 2010, p. 145-157)

MÖRCHEN, Hermann. Adorno und Heidegger: Untersuchung einer philosophischen Kommunikationsverweigerung. Stuttgart: Klett-Cotta, 1981.

NAEHER, Jürgen. Das ontologische „Bedürfnis im Denken“: Der Erste Teil der Negativen Dialektik (67-136). Zum Verfahren der ,immanenten Kritik'. In:

(Hrsg.). Die Negative Dialektik Adornos. Opladen: Leske und Budrich, 1984, p. 204-234.

NEVES SILVA, Eduardo S. Filosofia e arte em Theodor W. Adorno: A categoria da constelação. Tese (Doutorado). Programa de Pós-Graduação em Filosofia, Faculdade de Filosofia e Ciências Humanas, Universidade Federal de Minas Gerais. Belo Horizonte, 2006. 
NEVES SILVA, Eduardo S. Adorno, Heidegger, metafísica e ontologia. In: PUCCI, B.; FRANCO, R.; GOMES, L. R. (orgs.). Teoria crítica na era digital: Desafios. São Paulo: Nankin, 2014, p. 217-224.

PLATÃO. O Banquete. Ed. bilíngue. Trad., posfácio e notas de José Cavalcante de Souza. São Paulo: Editora 34, 2016.

THOMÄ, Dieter. Verhältnis zur Ontologie: Adornos Denken des Unbegrifflichen. In: HONNETH, Axel; MENKE, Christoph (eds.).Theodor W. Adorno: Negative Dialektik. Berlim: Akademie Verlag, 2006, p. 29-48.

WEBER, Max. A ética protestante e o "espírito" do capitalismo. Trad. J. M. M. de Macedo. São Paulo: Companhia das Letras, 2004.

ZUIDERVAART, Lambert. Social Philosophy after Adorno. Cambridge, UK: Cambridge UP, 2007.

Endereço do Autor:

Rua da Campina, 140, Apto. 2205

Ponta Negra

59090-480 Natal - RN

luizphilipedecaux@gmail.com 